\title{
UNITED KINGDOM'S ROLE IN COMMONWEALTH DEVELOPMENT
}

T HE Overseas Resources Development Bill received its second reading in the House of Commons on January 28, and in the House of Lords on February 18. It is intended to give effect to the policy for the Colonial Development Corporation, which is set forth in the White Paper* of July 1957, on the United Kingdom's role in Commonwealth development. The Government believes that it would be inappropriate for a United Kingdom statutory corporation concerned especially with the United Kingdom's responsibilities towards its dependent territories to invest money in new schemes in any territory after independence, although the Government would be happy to see the Corporation's manangerial experience continue to be available to any newly independent Commonwealth country, or to any Commonwealth country which might desire it, and this is provided for under Cleuse $I$. The Government also agrees with the Corporation's view that further capital will be required if the Corporation is to embark on fresh projects in Colonial territories, and Clause 2 of the Bill increases the amount which it may borrow and have outstanding at any one time from $£ 100$ million to $£ 150$ million, and the amount which may be advanced from the Exchequer to the Corporation from $£ 100$ million to £130 million outstanding.

As the Secretary of State for the Colonies, Mr. Lennox-Boyd, explained in moving the second reading, the Bill is concerned with only one section of the broad field covered by the White Paper. Over the years 1953-56 the average investment in the whole Commonwealth, including special assistance to various Colonial territories, was nearly $£ 200$ million a year, representing 1.25 per cent of our average gross national product, or 7-8 per cent of our gross fixed investment at home. It is estimated that in the decade 1946-57, 70 per cent of the external capital invested in the sterling Commonwealth came from the United Kingdom, 15 per cent from the United States, 10 per cent from the International Bank for Reconstruction and Development, and 5 per cent

* The United Kingdom's Role in Commonwealth Development. Pp. 18. (Cmnd. 37.) (London: H.M. Stationery Office, 1957.) 1s. net. from other sources. The Bill was generally welcomed, though reservations were expressed as to whether the increase in capital was sufficiently large, and the Government's view that reliance should be placed on capital from private sources was challenged by Lord Lucan and Lord Milner. The Earl of Perth, in replying, pointed out that private sources had invested fourteen times as much as the Council Development Corporation in the Colonies during 1954-56.

The sections in the White Paper of most direct interest to the scientist and technologist-those dealing with technical co-operation and with cooperation in the field of nuclear science-lay outside the scope of the debate. As regards technical cooperation, it is estimsted that 4,234 Commonwealth students are taking courses at United Kingdom universities and university colleges in the current academic year and about 2,000 at technical institutes, etc. Under the Colombo Plan Technical Co-operation Scheme it is planned to spend $£ 750,000$ for Commonwealth countries and $£ 250,000$ for foreign countries in the current financial year, and the Government believes that the sum of $£ 7$ million to be made available for the seven years from April 1956 should meet probable requirements under the Colombo Plan in that period.

The section on nuclear science reviews the development of co-operation in this field and then affirms the Government's intention to give all possible assistance to other Commonwerlth countries, including the Colonial territories, in developing nuclear energy to meet their individual requirements. The Atomic Energy Authority does its best to give priority to candidates from other parts of the Commonwealth in its own schools, and Commonwealth countries intending to establish a nuclear project of their own can look to the Authority for help on organization and objectives, and advice on design of laboratories, selection of equipment, safety precautions, etc. Nuclear scientists from Commonwealth countries are to be invited to an informal meeting in the United Kingdom following the 1958 United Nations Conference on nuclear energy.

\section{TURNOVER OF PROTEIN IN A NON-MULTIPLYING ANIMAL CELL}

\author{
By DR. H. HARRIS and J. W. WATTS \\ Sir William Dunn School of Pathology, University of Oxford
}

F protein turnover is defined as concurrent synthe-
sis and degradation of protein within the cell, the
experiments of Hogness, Cohn and Monod ${ }^{1}$, Rotman
and Spiegelman ${ }^{2}$ and Koch and Levy ${ }^{3}$, have shown
that in Escherichia coli, during the exponential
phase of growth, no detectable turnover of protein
occurs. These findings have led Hogness et al. ${ }^{1}$ to
question whether the proteins of animal cells turn
over, it having been generally assumed, since the
work of Schoenheimer, that they do. In recent
discussions of the problem of turnover Cohn ${ }^{5,6}$ has
pointed out that the evidence on which the demon-
stration of protein turnover in animal cells rests is
inconclusive; the results could be explained by con- current multiplication and death of cells in the tissues or by secretion of protein by the cells. Cohn has suggested that a precise answer to this problem could be obtained by studying a homogeneous population of animal cells growing exponentially in vitro. A study of this sort has been carried out by Siminovitch and Graham?, who found that in mouse fibroblasts growing exponentially in suspension cultures no turnover of ribonucleic or deoxyribonucleic acids occurred. However, in the animal, exponential multiplication of cells rarely, if ever, occurs. Some cells, such as those of the brain, undergo no multiplication at all during adult life; and in tissues where cells do multiply the rate of mitosis is normally adjusted to 